\title{
Genetic differentiation in the genus Uroconger in the Indo-Pacific region
}

\author{
Tao Ma ${ }^{1, *}$, Jun Aoyama ${ }^{1}$, Michael J. Miller ${ }^{1}$, Yuki Minegishi ${ }^{1}$, Jun G. Inoue ${ }^{2}$, \\ Katsumi Tsukamoto ${ }^{1}$
}

\begin{abstract}
${ }^{1}$ Ocean Research Institute, The University of Tokyo, 1-15-1 Minamidai Nakano-Ku, Tokyo 164-8639, Japan
${ }^{2}$ 150R Dirac Science Library, Florida State University, Tallahassee, Florida 32306-4120, USA
\end{abstract}

\begin{abstract}
Only a few species of congrid eels of the genus Uroconger (Congridae) have been described worldwide, but between these species each of the adult and larval morphologies are very similar. $U$. lepturus is the only species currently recognized in the Indo-Pacific, however, previous morphological counts of the total myomeres of Uroconger leptocephali suggest that more than 1 species may occur in this region. In this study, 1222 sites of the mitochondrial 16S rRNA gene were determined from 54 Uroconger leptocephali and one adult $U$. lepturus collected from 2 different regions of the Indo-Pacific to examine their genetic differentiations. The neighbor-joining tree based on Kimura's 2-parameter distances showed 4 major groups among the specimens examined, including one with the $U$. lepturus adult. The average inter-group genetic distances were 0.0348 to 0.0648 , almost 20 times greater than the intra-group distances (0.0028 to 0.0036), and the former were larger than the distances between species in some other eels, such as those of the genera Conger and Anguilla. No clear geographic differentiation was found, but a highly significant difference was found between the 2 closest sister Groups A and B $\left(F_{\mathrm{ST}}=0.90062, \mathrm{p}<0.05\right)$. However, the key characters of both the total number of myomeres and the position of the last vertical blood vessel overlapped among the genetic groups. These findings suggest the possibility of the presence of cryptic lineages within the genus Uroconger in the Indo-Pacific region.
\end{abstract}

KEY WORDS: Uroconger $\cdot$ Genetic differentiation $\cdot$ Indo-Pacific

\section{INTRODUCTION}

The congrid eels of the genus Uroconger are demersal tropical and subtropical fishes that live mainly along the continental margins and reach sizes of about $50 \mathrm{~cm}$ in length (Smith 1989a). They usually occur on soft mud or sandy bottoms and feed mainly on small benthic crustaceans (Froese \& Pauly 2006), but little is known about their ecology and life history. The genus Uroconger presently only includes 2 or 3 species worldwide, but it is difficult to morphologically distinguish either the adults or the leptocephali of these species (Smith 1989a,b).

A single species, Uroconger syringinus, is known from both the western and eastern Atlantic (Smith 1989a, Froese \& Pauly 2006). Another single species, Uroconger lepturus, is widely distributed from the western Indian Ocean to the western Pacific, as far north as Japan (Castle 1968, Smith 1989a), and it appears to be an abundant species of marine eel in the western Indian Ocean (Amir et al. 2005). A reported third species, Uroconger erythraeus, is restricted to the Red Sea (Klausewitz 1994), but its morphological differences from $U$. lepturus are still not clear.

Smith (1989a) examined morphological variation in Uroconger syringinus and Uroconger lepturus from different regions and found slight differences that suggested some regional divergence in morphological characters. Examinations of Uroconger leptocephali from the Indo-Pacific showed a wide range in the total number of myomeres (TM, corresponding to the total number of vertebrae [TV] in adults), suggesting more than 1 species of Uroconger may occur in the region (Smith 1989a). 
The development of molecular genetic techniques has revealed that various marine species considered to have large geographic distributions are often complexes of morphologically similar, but genetically distinct, species (Knowlton 2000). These techniques have played an important role in recognizing cryptic or sibling species in a variety of marine taxa such as invertebrates, fishes, and mammals (Knowlton 1993, Garcia-Rodriguez et al. 1998, Lima et al. 2005, Bickford et al. 2007). This has also been found to be true for bonefishes (Elopomorpha, Albuliformes) in the IndoPacific (Colborn et al. 2001), which also have a leptocephalus larva and are closely related to eels (Elopomorpha, Anguilliformes). The finding of several cryptic species of bonefishes suggests that this type of population differentiation in widely distributed species could exist in some species of eels such as Uroconger.

In the present study, the mitochondrial DNA (mtDNA) 16S rRNA genes of Uroconger leptocephali, and one $U$. lepturus adult, collected from different locations in the Indo-Pacific, were partially sequenced to examine their genetic differentiations. The genetic differences and speciation mechanisms within the genus Uroconger in the Indo-Pacific are then discussed.

\section{MATERIALS AND METHODS}

Collection and measurement. As part of a larger study on many taxa of congrid leptocephali in the IndoPacific region, 54 Uroconger leptocephali collected in the East China Sea (ECS), eastern Indian Ocean (EIO) and western North Pacific (WNP) (Table 1, Fig. 1) were examined morphologically and genetically. These collections were made during the 3 research cruises of KT-00-16 (5 to 6 December 2000, 29 stations), BJ-03-2 (5 to 20 June 2003, 25 stations), and KH-04-2 (2 July 2004, only 1 station south of Japan was included; a single deep tow using $4000 \mathrm{~m}$ of wire not specifically targeting leptocephali). The details of the first 2 sampling surveys have been previously described (Miller et al. 2002, Aoyama et al. 2007).

Leptocephali were collected using a large pelagic trawl (Isaacs Kidd Midwater Trawl [IKMT]) with an $8.7 \mathrm{~m}^{2}$ mouth opening and either 1.0 or $0.5 \mathrm{~mm}$ mesh that was fished in both oblique and step tows (generally tows were in the upper $300 \mathrm{~m}$ or shallower). After collection, the leptocephali were sorted fresh from the plankton, measured to the nearest $0.1 \mathrm{~mm}$ total length (TL), and the 2 key morphological characters of an Uroconger leptocephalus, the TM and position of the last vertical blood vessel (LVBV), were counted in all specimens. They were identified at the genus level based on Smith (1989b), and then preserved in $95 \%$ ethanol.
Table 1. Uroconger. The collection data and total length (TL) of the 54 leptocephali and single adult specimens used in this study. The adult was U. lepturus. Locations: ECS: East China Sea, EIO: eastern Indian Ocean, WNP: western North Pacific

\begin{tabular}{|lllcc|}
\hline Location & \multicolumn{1}{c}{ Cruise } & Date & N & \multicolumn{1}{c|}{ TL (mm) } \\
\hline Leptocephali & & & & \\
ECS & KT-00-16 & 5-6 Dec 2000 & 8 & $46.5-99.9$ \\
EIO & BJ-03-2 & 5-20 Jun 2003 & 45 & $16.0-143.4$ \\
WNP & KH-04-2 & 2 Jul 2004 & 1 & 111.7 \\
Total & & & 54 & $16.0-43.4$ \\
Adult & & & & \\
Kagoshima & - & Aug 28, 1998 & 1 & 381 \\
\multicolumn{1}{l}{ Bay } & & & & \\
\hline
\end{tabular}

Based on previous research (Smith 1989b, Ma 2006), the leptocephali included in the present study were both morphologically and genetically identified as belonging to the genus Uroconger. The leptocephali of Uroconger have a distinct single row of pigment spots along the midline, and are easily distinguished from other congrid leptocephali that have similar pigmentation by their high numbers of TM (Smith 1989b). A genetic comparison of these leptocephali to 6 known genera and 8 unknown taxa of congrid leptocephali

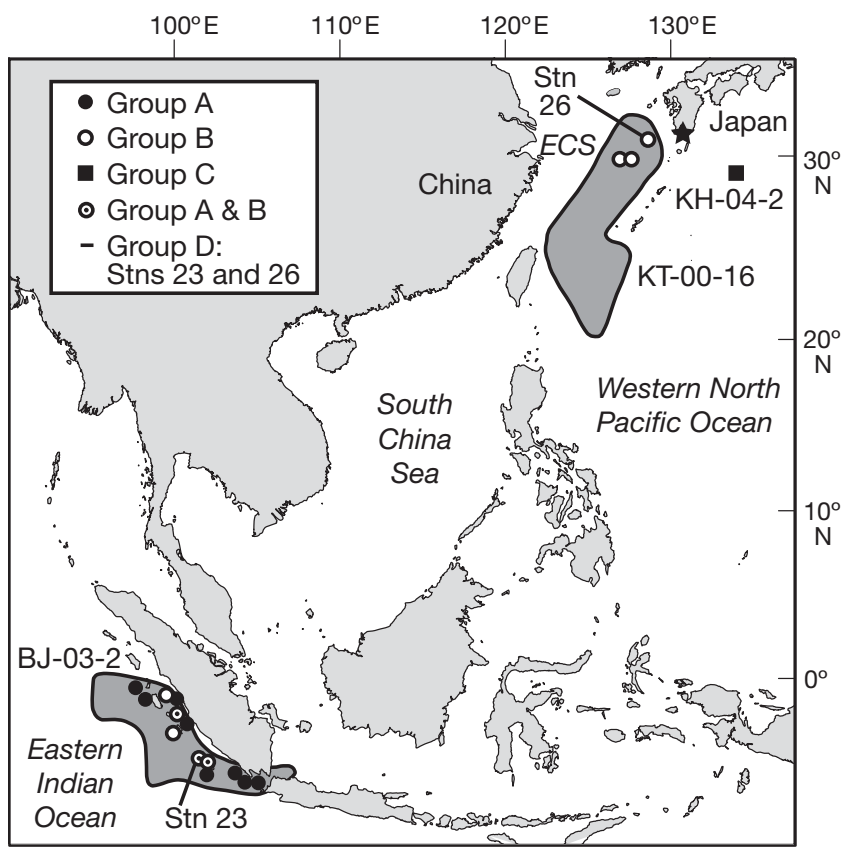

Fig. 1. Uroconger. Sampling locations of the Uroconger leptocephali (circles and squares) and the adult specimen of $U$. lepturus (black star) examined in this study. Stations where the leptocephali of each genetic group were collected are shown, along with the outline of the sampling regions of the KT-00-16 and BJ-03-2 surveys (dark grey shading). Stn 26 and Stn 23 are the locations where leptocephali genetically grouped with the adult specimen of $U$. lepturus were collected 
clearly showed that the leptocephali morphologically identified as belonging to the genus Uroconger formed a distinct monophyletic clade (Ma 2006). In addition, there are no other known species of eels in the subfamily Congrinae present in the Indo-Pacific that have such a high range of TV (Froese \& Pauly 2006, Ma 2006), except for Gavialiceps spp. whose leptocephali do not have lateral pigment (Karmovskaya 1994).

The adult specimen of Uroconger lepturus ( $\mathrm{TL}=$ $381 \mathrm{~mm}$ ) was collected during a trawling survey for benthic fishes in Kagoshima Bay carried out by Kagoshima University on 28 August 1998 (Table 1, Fig. 1). It was identified according to Hatooka (2000) and frozen after collection. This adult specimen was then deposited in the National Science Museum, Tokyo, Japan (NSMT-P71849).

PCR and sequencing. A portion of the body of the leptocephali and the musculature of the adult were used for DNA extraction and amplification. Total genomic DNA of each specimen was extracted by incubation in $500 \mu \mathrm{l}$ of a $5 \%$ chelex solution (Bio Rad) at $98^{\circ} \mathrm{C}$ for $15 \mathrm{~min}$. A fragment of the mtDNA $16 \mathrm{~S}$ rRNA gene was amplified via polymerase chain reactions (PCRs) using the 4 oligonucleotide primers: L1854 (5'-AAA CCT CGT ACC TTT TGC AT-3'), L2510 (5'CGC CTG TTT AAC AAA GAC AT-3'), H2582 (5'-ATT GCG CTA CCT TTG CAC GGT-3'), and H3058 (5'TCC GGT CTG AAC TCA GAT CAC GTA-3') (Inoue et al. 2000). PCRs were performed in a Model 9700 thermal cycler (Applied Biosystems) with a total of $15 \mu \mathrm{l}$ reaction volume containing $0.2 \mathrm{mM}$ of each deoxyribonucleotide triphosphate (dNTP), $1.5 \mu \mathrm{l}$ of $10 \times$ PCR buffer (Takara), $0.5 \mu \mathrm{M}$ of each primer, $0.3 \mathrm{U}$ of Taq DNA polymerase (Takara), and $0.6 \mu \mathrm{l}$ of template. Typical amplification parameters were 30 cycles of denaturation at $94^{\circ} \mathrm{C}$ for $15 \mathrm{~s}$, annealing at $50^{\circ} \mathrm{C}$ for $15 \mathrm{~s}$, and extension at $72^{\circ} \mathrm{C}$ for $20 \mathrm{~s}$ after heating at $94^{\circ} \mathrm{C}$ for $5 \mathrm{~min}$.

PCR products were electrophoresed on a $1.0 \%$ agarose gel L03 (Takara), and later stained with ethidium bromide for band characterization via ultraviolet transillumination. Double-stranded PCR products were purified using a Pre-Sequencing Kit (USB), that employs the shrimp alkaline phosphatase and exonuclease to remove excess dNTPs and oligonucleotides, and the purified products were subsequently used for direct cycle sequencing with dye-labeled terminators (Applied Biosystems). All sequencing reactions were performed according to the manufacturer's instructions with the same primers as those for PCR. Labeled fragments were analyzed on a Model 3100 or 3130 genetic analyzer (Applied Biosystems).

Sequence analysis. The DNA sequences were edited and analyzed with EditView v.1.0.1, AutoAssembler v.2.1 (Applied Biosystems), and DNASIS v.3.2 (HiTachi
Software Engineering). Then all sequences were aligned using the alignment software package Clustal X 1.83 (Thompson et al. 1997) with default gap penalties, and subsequently adjusted by eye using MacClade v.4.05 (Maddison \& Maddison 2002). These sequences were deposited in the DDBJ/ EMBL/GenBank nucleotide sequence databases with accession numbers: AB330934 to AB330988.

Analyses of genetic differentiation. The pairwise differences among samples were obtained by PAUP* v.4.0s (Swofford 2002), and Kimura's 2-parameter distances (Kimura 1980) were also calculated. Relationships between haplotypes were determined with Kimura's 2-parameter distance matrix using neighborjoining by PAUP* $4.0 \mathrm{~s}$. The fixation indexes $\left(F_{\mathrm{ST}}\right)$ between locations or haplotype groups were calculated, and their significance was tested by the permutation test (10000 permutations) using Arlequin 2.001 (Schneider et al. 2000).

\section{RESULTS}

The 54 Uroconger leptocephali examined had a wide range of TL (16.0 to $143.4 \mathrm{~mm}$ ) (Table 1), but they were generally similar in morphology. Eight Uroconger leptocephali (46.5 to $99.9 \mathrm{~mm} \mathrm{TL}$ ) were collected in the northern area of the ECS and were present at 3 of the 29 stations that were sampled in the region (Fig. 1). Off West Sumatra in the EIO, 45 Uroconger leptocephali (16.0 to $143.4 \mathrm{~mm} \mathrm{TL}$ ) were collected at the stations closer to the coast (Fig. 1), and were present at 13 of the 25 stations that were sampled. A single $111.7 \mathrm{~mm}$ TL specimen was collected in the WNP just to the east of the ECS (Fig. 1). The TM and LVBV ranged widely from 206 to 240 and 56 to 69, respectively, in these specimens (Table 2). Both the TM and LVBV counts overlapped among the 3 locations, and higher ranges of both characters were seen in the EIO specimens (Fig. 2a,c).

Pairwise sequence comparisons showed that there were 0 to 79 (0 to $6.5 \%$ ) site differences in the leptocephali examined based on 1222 sites of the mitochondrial 16S rRNA fragment. Among them, 1 specimen from the ECS (70.4 mm TL) and 1 specimen from the EIO (105.0 mm TL) showed very small sequence differences from the adult specimen of Uroconger lepturus, at only 6 and 8 sites $(0.5,0.7 \%)$, respectively.

The genetic analyses of the Uroconger sequence data showed that there were clear differences among the specimens. The neighbor-joining tree based on Kimura's 2-parameter distances identified 4 divergent groups, which were designated as Groups A, B, C and D (Fig. 3, Table 2). Most of the leptocephali were separated into 2 of the groups: Group A ( $\mathrm{N}=34$, all were 
collected in the EIO) and Group B $(\mathrm{N}=17$, collected from both the EIO and ECS). The 1 leptocephalus from the WNP was different from all the others and formed a separate Group C; and Group D consisted of the adult specimen of $U$. lepturus from Kagoshima Bay and a single leptocephalus from each of the ECS and EIO. The average intra- and inter-group genetic distances were 0.0028 to 0.0036 and 0.0348 to 0.0648 , respectively (Table 3 ). The $F_{\mathrm{ST}}$ showed clear genetic differentiation between Groups $\mathrm{A}$ and $\mathrm{B}\left(F_{\mathrm{ST}}=0.90062, \mathrm{p}<0.05\right)$, and for Group A, a significant difference was observed between the 2 subgroups A1 and A2 $\left(F_{\mathrm{ST}}=0.56085, \mathrm{p}<0.05\right)$. The genetic distance between these 2 subgroups was much lower, however (0.0051).

The TM and LVBV also overlapped in the 4 groups, and Group A had the widest range of TM (Fig. 2b,d, Table 2). Both the TM and LVBV of Group A (mean \pm $\mathrm{SD}: 223 \pm 7$ and $65 \pm 2$, respectively) were a little higher than those of Group B (218 \pm 7 and $63 \pm 4)$, and they were significantly different for TM $(t$-test, $\mathrm{p}=$ 0.03), but not for LVBV ( $U$-test, $\mathrm{p}=0.17$ ).

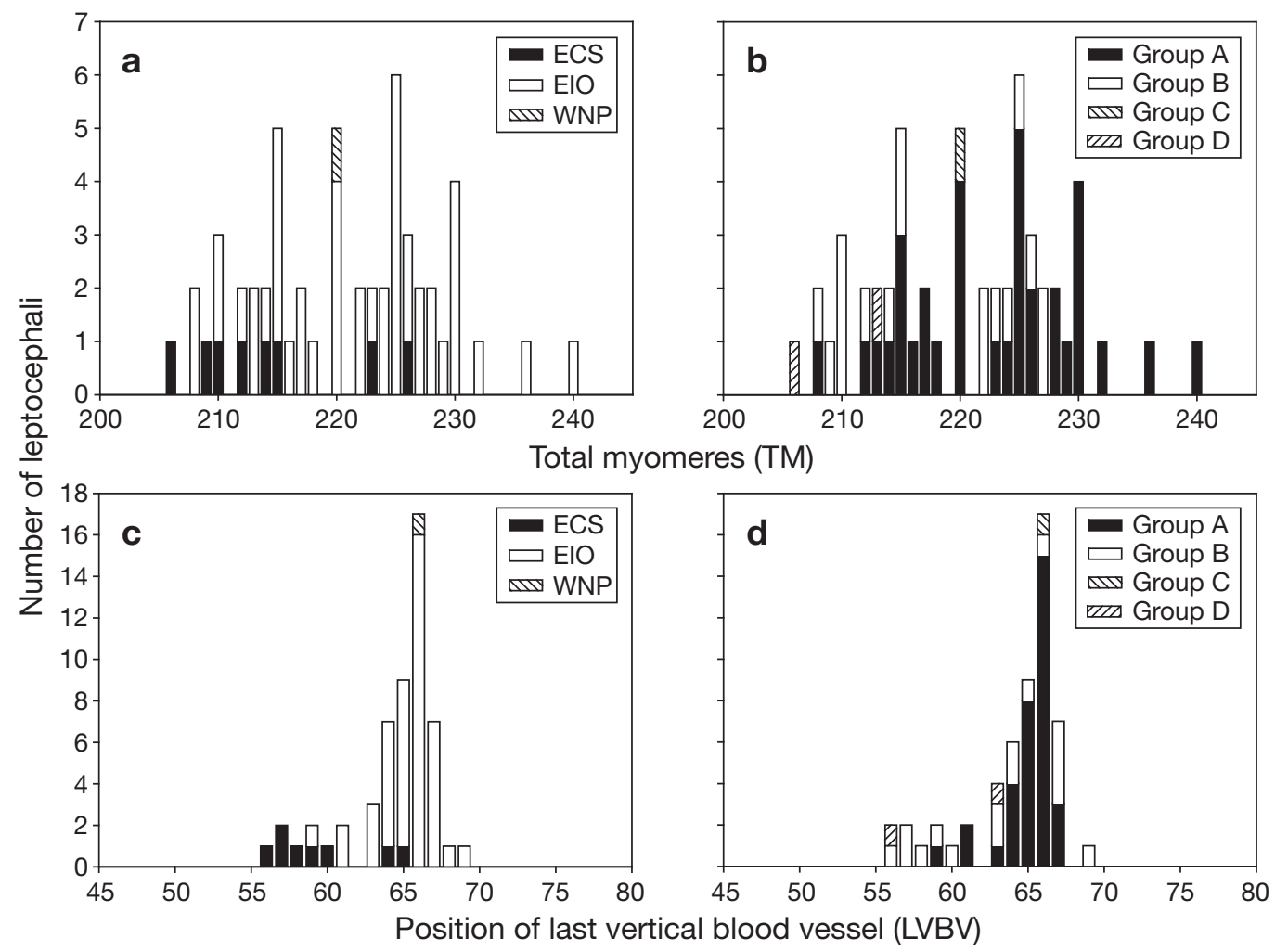

Fig. 2. Uroconger. Frequency distributions of $(\mathrm{a}, \mathrm{b})$ the total no. of myomeres, and $(\mathrm{c}, \mathrm{d})$ the position of the last vertical blood vessel of Uroconger leptocephali $(\mathrm{a}, \mathrm{c})$ collected at the 3 study area locations, and $(\mathrm{b}, \mathrm{d})$ of the 4 genetic groups that were mostly mixed among the study areas. ECS: East China Sea; EIO: eastern Indian Ocean; WNP: western North Pacific. N = 54
Genetic differentiation and cryptic lineages. The results of this study provided strong evidence of genetic differentiation in the genus Uroconger in the Indo-Pacific. Only one adult species of Uroconger is presently recognized across the wide areas of the IndoPacific, but this study identified at least 4 distinct genetic groups of Uroconger leptocephali, and most of them were sympatrically distributed in 2 locations (ECS and EIO) of the Indo-Pacific (Figs. 1 \& 3). Uroconger leptocephali (Wouthuyzen et al. 2005) and adults (Froese \& Pauly 2006) also have been found in the central Indonesian Seas, so the distributions of some of
Table 2. Uroconger. The genetic groups, total length (TL), total number of myoEast China Sea, EIO: eastern Indian Ocean, WNP. western North Pacific

\begin{tabular}{|c|c|c|c|c|c|c|c|}
\hline $\begin{array}{l}\text { Genetic } \\
\text { group }\end{array}$ & Location & $\mathrm{N}$ & $\begin{array}{c}\text { TL } \\
(\mathrm{mm})\end{array}$ & $\overline{\text { Range }}$ & $\begin{array}{l}\mathrm{TM} \\
\text { Mean } \pm \mathrm{SD}\end{array}$ & $\overline{\text { Range }}$ & $\begin{array}{l}\text { VBV } \\
\text { Mean } \pm \text { SD }\end{array}$ \\
\hline A & EIO & 34 & $16.0-143.4$ & $208-240$ & $223 \pm 7$ & $59-67$ & $65 \pm 2$ \\
\hline B & EIO, ECS & 17 & $20.8-126.0$ & $208-227$ & $218 \pm 7$ & $56-69$ & $63 \pm 4$ \\
\hline $\mathrm{C}$ & WNP & 1 & 111.7 & 220 & - & 66 & - \\
\hline D & ECS, EIO & 2 & $70.4,105.0$ & 206,213 & $210 \pm 5$ & 64,68 & $66 \pm 4$ \\
\hline
\end{tabular}

\section{DISCUSSION}


these groups may be continuous from the ECS to the EIO. Because the inter-group genetic distances $(0.0348$ to 0.0648 ) were almost 20 times greater than the intragroup distances (0.0028 to 0.0036), and the closest sister Groups A and B were genetically distinct based on the $F_{\mathrm{ST}}$ of $0.90062(\mathrm{p}<0.05)$, these 4 groups may represent 4 distinct lineages. The genetic distances of the 16S rRNA gene between the 4 different groups in this study were much larger than those $(0.0219)$ between the 2 species of east asian conger eels, Conger japonicus and C. myriaster (Ma 2006), and even larger than those (0.029 to 0.033) between the 2 species of Indonesian tropical freshwater eels, Anguilla celebesensis and $A$. interioris (Aoyama et al. 2000). The implication of the genetic differentiation within Group $\mathrm{A}\left(F_{\mathrm{ST}}=\right.$ $0.56085, \mathrm{p}<0.05)$ suggests there is some population structure within this group in the Indian Ocean, since the genetic distance between these subgroups was much lower (0.0051) than the inter-group genetic distances.

The Uroconger leptocephali examined here and in previous studies were very similar in morphology, but they have shown some geographic variation in TM. A clear variation in TM between the Uroconger leptocephali from the northeastern Indian Ocean (low range: 204 to 223) and those from Hawaii and New

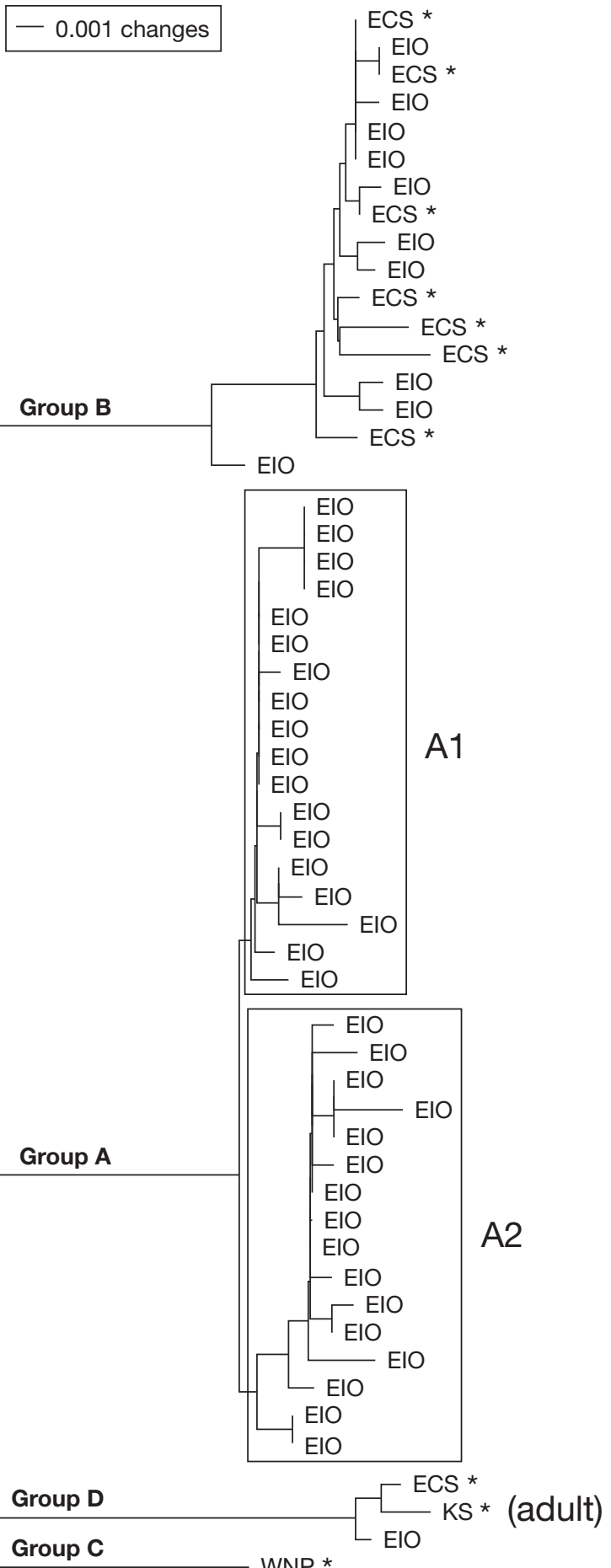

Fig. 3. Uroconger. Midpoint rooted neighborjoining tree based on Kimura's 2-parameter distances of 1222 sites of mtDNA 16S rRNA gene from 54 Uroconger leptocephali and one adult of $U$. lepturus collected in the Indo-Pacific. ECS: East China Sea; EIO: eastern Indian Ocean; WNP: western North Pacific; KS: Kagoshima Bay. * Pacific regions 
Table 3. Uroconger. Mean \pm SD pairwise Kimura 2-parameter genetic distances within and between the 4 genetic groups examined in this study

\begin{tabular}{|c|c|c|c|c|}
\hline Group & A & B & $\mathrm{C}$ & $\mathrm{D}$ \\
\hline A & $0.0036 \pm 0.0020$ & & & \\
\hline B & $0.0348 \pm 0.0020^{\mathrm{a}}$ & $0.0034 \pm 0.0020$ & & \\
\hline $\mathrm{C}$ & $0.0557 \pm 0.0017$ & $0.0612 \pm 0.0015$ & - & \\
\hline $\mathrm{D}$ & $0.0648 \pm 0.0015$ & $0.0598 \pm 0.0015$ & $0.0577 \pm 0.0019$ & $0.0028 \pm 0.0005$ \\
\hline \multicolumn{5}{|c|}{${ }^{\mathrm{a}} F_{\mathrm{ST}}=0.90062, \mathrm{p}<0.05$} \\
\hline
\end{tabular}

otolith studies on the leptocephali of other genera, must be greater than 100 d (Kimura et al. 2004, Ma et al. 2005). This long larval duration enables leptocephali to disperse over a geographically wide range, potentially increasing gene flow among different areas and reducing opportunities for allopatric speciation in areas connected by ocean currents.

Caledonia (high range: 235 to 243) was found by Smith (1989a), but similar geographic differences were not observed in this study (Fig. 2). Although there were some differences in the mean values of TM and LVBV among groups, our Uroconger leptocephali were still difficult to distinguish using only morphology due to overlapped ranges in both characters (Table 2, Fig. 2). The adult morphology of Uroconger eels also may be very similar, because only one species has been recognized in the wide region of the Indo-Pacific, and even the differences between the Indo-Pacific ( $U$. lepturus) and Atlantic ( $U$. syringinus) species are very slight (Smith 1989a). This suggests the strong possibility of cryptic lineages existing in the genus Uroconger in the Indo-Pacific, which may be found to represent cryptic species after further research.

Using molecular genetic techniques, discoveries of cryptic species are common in a variety of marine organisms. Many of these are widely distributed species (Lessios et al. 1999, Knowlton 2000, Colborn et al. 2001, Quattro et al. 2006) such as Uroconger lepturus, or various types of coral reef species (Rocha et al. 2005, 2007). A general pattern in marine organisms that consist of cryptic species living in sympatry is that the species often have differences in ecology or life history, and after closer examination they are found to have subtle differences in morphology (Knowlton 1993, 2000, Rocha et al. 2005, 2007). This may also be applicable to the Uroconger eels in the Indo-Pacific.

Speciation mechanisms. It is difficult to determine the mechanisms of speciation of marine organisms because of the size and connectivity of marine areas, and the high potential for dispersal in a transglobal aquatic medium. Most speciation is thought to occur in allopatry, and the degree of occurrence of sympatric speciation is controversial (Barluenga et al. 2006). There are a few examples of apparent sympatric speciation in fishes (Johannesson 2001, Munday et al. 2004, Barluenga et al. 2006), but its occurrence is difficult to establish except in isolated habitats without potential barriers, such as freshwater lakes.

In the case of Uroconger eels, they have an extended pelagic larval period, because their leptocephalus larvae grow to sizes up to at least $143 \mathrm{~mm}$ (Smith 1989b, Wouthuyzen et al. 2005, this study), which, based on
However, in the case of eels, dispersal capability itself does not necessarily translate into panmixia. Studies on the leptocephali of some congrid eels, such as Conger myriaster and C. conger, have suggested the possibility that these species may not be completely panmictic single spawning populations, despite their larval durations being very long (Kimura et al. 2004, Correia et al. 2006). Although the spawning areas of most congrid eels are not yet known, studies on anguillid eels have shown that they have evolved sitespecific spawning areas to which they return for reproduction, regardless of having a widespread larval dispersion (Tsukamoto et al. 2002). If this type of spawning site fidelity is also present in the marine eel Uroconger, it could tend to facilitate genetic divergence based on the evolution of region-specific adult spawning and larval recruitment behaviors.

Therefore, the presence of different Uroconger sympatrically distributed in the various areas of the Indo-Pacific may have been caused by allopatric divergence. Over the entire Indo-Pacific, allopatric speciation could have occurred in various distant regions, including other areas such as Hawaii, the western South Pacific, or the western Indian Ocean, where specific spawning areas and recruitment mechanisms may have been required. Some species could have then expanded their ranges into areas occupied by other Uroconger, thus resulting in the sympatric distributions suggested in the present study. Allopatric divergence is also suggested as the predominant speciation mechanism in bonefishes, which also have a leptocephalus larva and sympatrically distributed cryptic species, and biogeographical boundaries such as the emergent shallow Sunda Shelf (located in the southern South China and Java seas) have apparently played an important role, influencing the genetic structure of bonefishes (Colborn et al. 2001). Similar biogeographic factors associated with multiple changes of sea level also may have contributed to the genetic differentiation in sympatrically distributed Uroconger.

Genetic analyses of Uroconger specimens from the Indonesian Seas and more distant regions such as the western Indian Ocean, Hawaii, and the South Pacific may provide additional clues about the history of genetic divergence throughout the range of this genus 
and the possible presence of cryptic species. Future research should also examine the morphological, genetic, and life history differences in these eels using both adults and leptocephali to better understand the ecology and evolutionary history of the genus Uroconger in the Indo-Pacific region.

Acknowledgements. We thank Dr. Akihisa Torii, who provided the adult specimen of Uroconger lepturus. We acknowledge the hard work and assistance of the captain, crew and technicians of the RV 'Hakuho Maru', RV 'Tansei Maru' and RV 'Baruna Jaya VII' to make the larval sampling successful.

\section{LITERATURE CITED}

Amir OA, Berggren P, Ndaro SGM, Jiddawi NS (2005) Feeding ecology of the Indo-Pacific bottlenose dolphin (Tursiops aduncus) incidentally caught in the gillnet fisheries off Zanzibar, Tanzania. Estuar Coast Shelf Sci 63:429-437

Aoyama J, Watanaba S, Ishikawa S, Nishida M, Tsukamoto K (2000) Are morphological characters distinctive enough to discriminate between two species of freshwater eels, Anguilla celebesensis and A. interioris? Ichthyol Res 47:157-161

Aoyama J, Wouthuyzen S, Miller MJ, Minegishi Y and others (2007) Distribution of leptocephali of the freshwater eels, genus Anguilla, in the waters off west Sumatra in the Indian Ocean. Environ Biol Fishes 80:445-452

Barluenga M, Stolting KN, Salzburger W, Muschick M, Meyer A (2006) Sympatric speciation in Nicaraguan crater lake cichlid fish. Nature 439:719-723

> Bickford D, Lohman DJ, Sodhi NS, Ng PKL and others (2007) Cryptic species as a window on diversity and conservation. Trends Ecol Evol 22:148-155

Castle PHJ (1968) The congrid eels of the western Indian Ocean and the Red Sea. Ichthyol Bull (Grahamst) 33: $685-726$

Colborn J, Crabtree RE, Shaklee JB, Pfeiler E, Bowen BW (2001) The evolutionary enigma of bonefishes (Albula spp.): cryptic species and ancient separations in a globally distributed shorefish. Evolution 55:807-820

Correia AT, Faria R, Alexandrino P, Antunes C, Isidro EJ, Coimbra J (2006) Evidence for genetic differentiation in the European conger eel Conger conger based on mitochondrial DNA analysis. Fish Sci 72:20-27

Froese R, Pauly D (2006) FishBase. Accessed 31 Jul. www.fishbase.org

> Garcia-Rodriguez AI, Bowen BW, Domning D, MignucciGiannoni A and others (1998) Phylogeography of the West Indian manatee (Trichechus manatus): how many populations and how many taxa? Mol Ecol 7:1137-1149

Hatooka K (2000) Order Anguilliformes. In: Nakabo T (ed) Fishes of Japan with pictorial keys to species, 2nd edn. Tokai University Press, Tokyo, p 192-240 (in Japanese)

> Inoue JG, Miya M, Tsukamoto K, Nishida M (2000) Complete mitochondrial DNA sequence of the Japanese sardine Sardinops melanostictus. Fish Sci 66:924-932

Johannesson K (2001) Parallel speciation: a key to sympatric divergence. Trends Ecol Evol 16:148-153

Karmovskaya ES (1994) Systematics and distribution of the eel genus Gavialiceps (Congridae) in the Indo-West Pacific. J Ichthyol 34:73-88

Kimura M (1980) A simple method for estimating evolutionary rate of base substitutions through comparative studies of nucleotide sequences. J Mol Evol 16:111-120
Kimura Y, Ishikawa S, Tokai T, Nishida M, Tsukamoto K (2004) Early life history characteristics and genetic homogeneity of Conger myriaster leptocephali along the east coast of central Japan. Fish Res 70:61-69

Klausewitz W (1994) Comparative studies on the vertical distribution of bathybenthic deep-sea fishes of the Red Sea. Proc IPFC 4:462-468

Knowlton N (1993) Sibling species in the sea. Annu Rev Ecol Syst 24:189-216

Knowlton N (2000) Molecular genetic analyses of species boundaries in the sea. Hydrobiologia 420:73-90

Lessios HA, Kessing BD, Robertson DR, Paulay G (1999) Phylogeography of the pantropical sea urchin Eucidaris in relation to land barriers and ocean currents. Evolution 53: 806-817

$>$ Lima D, Freitas JEP, Araujo ME, Solé-Cava AM (2005) Genetic detection of cryptic species in the frillfin goby Bathygobius soporator. J Exp Mar Biol Ecol 320:211-223

Ma T (2006) Morphological variation and evolution of larval characteristics of congrid leptocephali in the Indo-Pacific region. $\mathrm{PhD}$ thesis, University of Tokyo

Ma T, Miller MJ, Shinoda A, Minagawa G, Aoyama J, Tsukamoto K (2005) Age and growth of Saurenchelys (Nettastomatidae) and Dysomma (Synaphobranchidae) leptocephali in the East China Sea. J Fish Biol 67: 1619-1630

Maddison DR, Maddison WP (2002) MacClade v.4.05. Sinauer, Sunderland, MA

Miller MJ, Otake T, Minagawa G, Inagaki T, Tsukamoto K (2002) Distribution of leptocephali in the Kuroshio Current and East China Sea. Mar Ecol Prog Ser 235:279-288

$>$ Munday PL, van Herwerden L, Dudgeon CL (2004) Evidence for sympatric speciation by host shift in the sea. Curr Biol 14:1498-1504

Quattro JM, Stoner DS, Driggers WB, Anderson CA and others (2006) Genetic evidence of cryptic speciation within hammerhead sharks (Genus Sphyrna). Mar Biol 148:1143-1155

Rocha LA, Robertson DR, Roman J, Bowen BW (2005) Ecological speciation in tropical reef fishes. Proc R Soc Lond B Biol Sci 272:573-579

Rocha LA, Craig MT, Bowen BW (2007) Phylogeography and the conservation of coral reef fishes. Coral Reefs 26: 501-512

Schneider S, Roessli D, Excoffier L (2000) Arlequin v.2001: a software for population genetics data analysis. Genetics and Biometry Laboratory, University of Geneva

Smith DG (1989a) Family Congridae. In: Böhlke EB (ed) Fishes of the western North Atlantic, Part 9, Vol 1: Orders Anguilliformes and Saccopharyngiformes. Sears Foundation for Marine Research, New Haven, CT, p 460-567

Smith DG (1989b) Family Congridae: leptocephali. In: Böhlke EB (ed) Fishes of the western North Atlantic, Part 9, Vol 2: Leptocephali. Sears Foundation for Marine Research, New Haven, CT, p 723-763

Swofford DL (2002) PAUP*: Phylogenetic analysis using parsimony ( ${ }^{*}$ and other methods), v.4.0 b 10. Sinauer Associates, Sunderland, MA

Thompson JD, Gibson TJ, Plewniak F, Jeanmougin F, Higgins DG (1997) The Clustal X windows interface: flexible strategies for multiple sequence alignment aided by quality analysis tools. Nucleic Acids Res 25:4876-4882

Tsukamoto K, Aoyama J, Miller MJ (2002) Migration, speciation and the evolution of diadromy in anguillid eels. Can J Fish Aquat Sci 59:1989-1998

Wouthuyzen S, Miller MJ, Aoyama J, Minagawa G and others (2005) Biodiversity of anguilliform leptocephali in the central Indonesian Seas. Bull Mar Sci 77:209-224

Submitted: August 7, 2007; Accepted: December 10, 2007

Proofs received from author(s): February 28, 2008 